\title{
POEMAS INÉditos de ALí ALÁH
}

\section{Presentación de Carlos Castro Jo}

Alí Aláh era el seudónimo de Santiago Navas, quien nació en Bluefields en 1955 y murió en Costa Rica en 1978. El poeta Alí Aláh publicó en 1977 un libro de poemas, "5 poemas costeños", el que le mereció su inclusión en "Panorama de la literatura nicaragüense" del excelente investigador e historiador Jorge Eduardo Arellano.

En su corta vida, Alí Aláh logró crear un estilo propio. Escribió versos de adjetivos atrevidos, con neologismos, juegos de palabras y puntuación original. En " 5 poemas costeños" logró expresar el ambiente del Caribe nicaragüense, especialmente el de la ciudad de Bluefields, a la que reconoce un carácter multiétnico. Él la describe así en el poema "Pimpóy Bailóp":

: Bluefields es un (burilado) crisol donde las pieles todas comulgan sus nostalgias --atlánticas

Estos poemas que ahora publica Wani son inéditos. Alí Aláh los escribió en medio de la lucha antisomocista y se siente en ellos el palpitar insurreccional. Estos son documentos históricos, que muestran el fervor de una época en la voz inconfundible de Alí Aláh.

Estos poemas se habían perdido, o por lo menos creíamos que se habían perdido. Alí Aláh le dio los originales al poeta David McField en los días agitados de la lucha antisomocista. Cuando las fuerzas sandinistas se preparaban para la insurrección, y temiendo que en un cateo de la Guardia Nacional los manuscritos se perdieran, el poeta McField me los dio para que los salvara. Con los poemas estaban también unos reportajes sobre la huelga de estudiantes en Bluefields y una carta al Knesset, el congreso de Israel, pidiendo que le cortaran el apoyo militar a Somoza. Yo puse todos esos papeles en un folder y los guardé con folletos y otros libros subversivos de la época, como "Hora cero" del poeta Ernesto Cardenal. Pero en las primeras semanas después del triunfo, cuando los sandinistas todavía estaban persiguiendo a los somocistas, los poemas de Alí Aláh se perdieron.

Ocurrió así: después del triunfo saqué esos materiales de sus escondites y me los llevé a la casa de la Juventud Sandinista, donde estábamos tratando de organizar a los jóvenes de Bluefields. En esos días, yo había recuperado un montón de fólderes de las casas de los somocistas de Bluefields y los había puesto inadvertidamente sobre el folder donde tenía los manuscritos de Alí Aláh. Domingo Navas, el hermano del poeta, me había hablado de que estaba interesado en saber qué había en esos fólderes, y yo le dije que los mandara a traer. El día en que un compañero llegó por los fólderes, yo estaba en una reunión, y sólo le dije donde estaban para que él los agarrara y se los llevara.

No fue sino varios días después que me acordé de que el folder con los poemas de Alí Aláh estaba con los fólderes que se llevó el compañero. Domingo Navas y yo hicimos el intento de recuperarlos pero ya se habían perdido en el alboroto de los primeros días del triunfo. Pasé muchos años pensando en esos poemas, hasta que un día, en el año 2008, hablando con William Howard, juez del distrito penal de Boaco, volví al tema de los poemas de Alí Aláh. Fue entonces que William, quien también había escrito poesía en su juventud y publicado su librito de poemas en 1980, me dijo que él me tenía una sorpresa. Y se fue a sus archivos, extrajo unos papeles, y puso en mis manos estos poemas de Alí Aláh. "Yo los pasé a máquina”, me dijo. “¿usted me está hablando de estos poemas?”. Desde que leí la primera página me di cuenta que William Howard había salvado esos poemas. No eran los manuscritos, pero eran los mismos poemas, ahora mecanografiados, recuerdos también de una época en que las computadoras personales no existían, o, por lo menos, no habían llegado a Nicaragua.

Y esos poemas perdidos son los que usted, querido lector, tiene en sus manos.

\section{Carlos Castro Jo}




\section{Puente de las Américas}

(sine qua non):

Si vas a cruzar este puente identifícate con mi gente...

Al corpiño no antojes magnolias

primaveras rosadas

ni paisajes benignos $\mathrm{y} / \mathrm{o}$

-primores-

bazares de dichas sino

cruenta historia

MARTIR PUEBLO EN COMBATE

...apresura el paso...

$$
\text { y atrinchérate...! }
$$

\section{(ah}

"en tu país...?):

:Si vas a cruzar este puente

identifícate con mi gente...!

-a gaspar garcía 1.- 1978

\section{EPOPEYA}

Densa noche lúgubre

constélase...

Novos aires francos

vislúmbranse...

El pueblo

está

en las calles.

Volcando

va

las vallas.

Las fosas

no

le arredran...:

Tira -tirano-: tira

(¡tirita!):

púrpura ocaso

aquí

feneció...

-prepárate,

compañero,

pronto

va

amanecer...!

15/sep./78

\section{Insinuación para siempre aprender a decir que no}

Apedreemos la comida

adentro de mis versos...

carilánguidos siguen la trayectoria

-dura-

que sus arduas luchas las marcan...

...Una multitud de hombres nace

adentro de mis versos

\section{$\mathrm{y}$}

adentro de sus pueblos

ellos no me nombran...

una multitud de versos gime

adentro de mis hombres

$$
\begin{gathered}
\text { y } \\
\text { adentro de sus pueblos } \\
\text { ellos sólo nombran } \\
\text { mis versos...! }
\end{gathered}
$$

1970 -ya en la mesa servida-

(iy a la mesa!)

porque cada grano o fibra de hambre

-y/o de alimento-

es una burla...

Una desdentada inmensa burla sádica...!

apredrea

apedreemos los asientos

la silla, el sofá, la mecedora,

muro, bacinilla o lo que sea

la sillantropófaga

$$
\text { del "presidente"... }
$$

...apedrearemos los asientos porque

son un castigo

un suplicio más locuaz

que la litera... pero
sobre todo 
la letrina:

la burla más "formal” colgando al intestino -porque:

... si hemos de apedrear la comida...

...consecuencia:

que deriva...

apedrearemos también la consecuencia

LA DERIVA

es decir:

apedrearemos todo cuanto salte

$$
\begin{aligned}
& \text { cuanto surja } \\
& \text { cuanto siga... }
\end{aligned}
$$

...el Verbo...

-¡también apedrearemos el poema!-

... apedrearemos -en fin- la piedra

-apedreemos la piedra!-

...y la pedrada...

1971

\section{Plan para turistas y emigrantes}

...Cuando cruces la frontera

Pregona en casa del vecino

Que nuestro hogar esta convulsionado

$\mathrm{Y}$ en plan de redimirnos

Del ogro panorama

-(¡eslabones!)

Refiereles

Que -dia a dia-

Las ferrosas trancas de los ventanales violentamos

En procura de que el techo se nos abra

Y limpido penetre el sol

-con toda su constelación de rojos cuerpos-

A inaugurarnos nova ruta

Ansi a d a...

(que con sus huestes siniestral porfia

Esquizofrenico el cavernicola...)

Diles

Que irreductibles los innumeros cadáveres

De nuestros proceres inmolados por la idea
Desde sus sencillas tumbas

Trazan pautas mapamores de combate

Sobre jóvenes conciencias que se empinan

Para verle al sol su desnudez equitativa

(que las vertientes ciertamente surte ecos

En la multitud de barquichuelos de la flota

Que hacia el horizonte marcha...)

Anunciales

Que -aunque lontana el alba-

( en el frontis negra loma se empecina!)

Con escrupulo de pueblo sometido

Aquí

Redoblaremos el ritmo de batalla

Hasta que -pleno el sol-

Fundemos la patria

Que nuestros proceres querian...!

Ah

\section{Confiésales}

Que somos sus hermanos en la lucha...

ALI ALAH

Octubre -1977-

Nota al transcriptor: favor copiar "al calco" -identicamente.- 